Eur. J. Clin. Chem. Clin. Biochem.

Vol. 30, 1992, pp. $531-535$

(C) 1992 Walter de Gruyter \& Co. Berlin - New York

\title{
A Fully Automated Enzyme Immunoassay for the Measurement of Cortisol in Biological Fluids
}

\author{
By T. Bacarese-Hamilton, R. Cattini, Colin Shandley, Clive Howard, R. Palmer and K. McFarthing
}

Serono Diagnostics Limited, Woking, Surrey, United Kingdom

(Received January 28/May 11, 1992)

Summary: This paper describes a fully automated assay on the Serono SR1 ${ }^{\mathrm{TM}}$ for the measurement of cortisol in serum, heparinised plasma and urine. The assay incorporates a specific polyclonal antibody to cortisol and cortisol conjugated to alkaline phosphatase as a label. Following immunoincubation, bound and free labelled cortisol are separated by magnetic sedimentation of the antibody complex. Phenolphthalein is liberated by the enzymatic hydrolysis of the substrate (phenolphthalein monophosphate) and the absorbance generated is measured as the assay end-point. All processing steps are performed by the SR1.

The assay has good analytical performance with respect to precision (within and between run CVs less than 10 and $11.5 \%$ respectively), detection limit (less than $5 \mathrm{nmol} / \mathrm{l})$ and recovery of added cortisol $(100 \pm 10 \%)$. The assay agrees well with cortisol concentrations determined by ID-MS and by established immunoassays $(r>0.96)$. Reference ranges of normal urine samples (pretreated by solvent extraction) are in good agreement with accepted values.

The study demonstrates that the SR1 Cortisol assay on the SR1 analyzer is suitable for the routine determination of cortisol in serum, heparinised plasma and urine samples.

\section{Introduction}

The measurement of serum cortisol is useful in the evaluation of both adrenal and pituitary function and in the differentiation of the pathological conditions associated with dysfunction of the pituitary-adrenal axis (1). Urinary cortisol provides high diagnostic sensitivity for hypercorticoidism (2). Immunoassays for the determination of urinary cortisol tend to omit chromatographic purification steps, so that cortisol metabolites contribute to the analytical value. In view of the lack of specificity of these methods, sample pretreatment is recommended (3).

Various manual and semi-automated immunoassay methods have been described for the measurement of cortisol; these include radioimmunoassay (4), chemiluminescence (5) and fluorescence polarization (6) immunoassay. Very recently, the first report of an automated immunoassay for cortisol has appeared in the literature (7).
This study describes the performance of a fully automated enzyme immunoassay for cortisol using the SR1 ${ }^{\mathrm{TM}}$ analyzer (Serono Diagnostics) with reference to its suitability for routine use in a clinical chemistry laboratory.

\section{Materials and Methods}

Assay specific reagents were provided by Serono Diagnostics S. A., Coinsins, Switzerland.

Human serum was collected from donors $(n=200)$ at a blood transfusion clinic. Urine samples were collected from normal, ambulatory individuals $(\mathrm{n}=29)$. Serum and plasma samples were also collected from the routine workload of two chemical pathology laboratories $(n=105)$. All samples were stored at $-20^{\circ} \mathrm{C}$ until they were assayed.

Commercial control sera (Lyphochek ECS Controls 1, 2 and 3 Lot No. 60000) were purchased from BioRad Laboratories, Herts, UK.

Cortisol-free human serum (Code 3SH015) was purchased from Scantibodies, San Diego, USA. 
Pure cortisol (USP grade) was purchased from the United States Pharmacopeial Convention, Maryland, USA.

All potential cross-reactants (tab. 2) were purchased from Sigma, Dorset, UK.

BCR Control Material (RM192/193) was supplied as reference sera by the Community Bureau of Reference (Commission of the European Communities) (8).

Commercial immunoassay kits were obtained from:

Diagnostic Products Corporation (DPC), Los Angeles, California, USA

Amerlite Diagnostics Limited, Amersham, UK

Boehringer Mannheim GmbH Diagnostica, Tutzing, Germany Abbott Diagnostics Division, Chicago, Illinois, USA

\section{Analytical procedure}

All cortisol determinations were performed using the SR1 Cortisol assay on the SR1 TM analyzer (Serono Diagnostics). The SR1 Cortisol assay uses a rabbit anti-cortisol polyclonal antiserum in an enzyme immunoassay. Fluorescein-conjugated antibody and a cortisol derivative conjugated to calf intestinal alkaline phosphatase (EC 3.1.3.1) are added to samples or standards. The reactants are incubated at $37^{\circ} \mathrm{C}$ for 12 minutes. During the incubation, cortisol in the sample or standard (50 $\mu$ l) competes with the enzyme-labelled cortisol derivative (150 $\mu \mathrm{l})$ for binding to the fluorescein-labelled antibody $(150 \mu \mathrm{l})$. At the end of this incubation, anti-fluorescein coupled to a magnetic solid phase is added $(200 \mu \mathrm{l})$. This rapidly (6 minutes incubation) binds to the antibody complex and is sedimented in a magnetic field. After aspiration of the liquid and washing of the solid phase, a solution of the enzyme substrate (phenolphthalein monophosphate) is added and the mixture incubated at $37^{\circ} \mathrm{C}$ for 12 minutes. At the end of this period the reaction is stopped by the addition of sodium hydroxide (final $\mathrm{pH}=10.6)$ and the intensity of the colour developed is measured photometrically. The intensity of the colour developed is inversely proportional to the concentration of cortisol in the sample or standard. The concentration of cortisol is calculated from a stored standard curve. The time to first result is 46 minutes; 59 samples can be processed in 120 minutes.

\section{Precision}

Within assay precision was determined by replication $(n=20)$ of three levels of control sera. To assess between assay precision, three levels of control sera were assayed in duplicate on ten occasions over a period of one month using 2 lots of reagents $(\mathrm{n}=20)$.

\section{Recovery and accuracy}

The recovery of the assay was determined by adding pure cortisol at different levels to 5 serum pools with low endogenous levels of cortisol. Recovery of added cortisol was calculated as recommended by the ECCLS guidelines (9).

Accuracy was determined by assaying the BCR material on 6 occasions. This material is supplied with cortisol concentrations assigned by isotope dilution - mass spectrometry (ID-MS).

\section{Detection limit}

The detection limit of the assay was defined as the concentration of cortisol equivalent to the mean absorbance of the zero standard minus two standard deviations calculated from 20 replicates of the zero analyte standard.

\section{Specificity}

The specificity of the assay was determined by measuring the apparent response to various potentially cross-reacting substances. Cross-reactivity was calculated as:

$$
\begin{aligned}
& \text { Cross-reactivity }(\%) \\
& =\frac{\text { Apparent cortisol dose }(\mathrm{nmol} / \mathrm{l})}{\text { Added dose cross-reactant }(\mathrm{nmol} / \mathrm{l})} \times 100
\end{aligned}
$$

\section{Dilution}

Accuracy was also monitored by assaying ten patient pools diluted with human cortisol-free serum.

\section{Expected values}

Reference ranges for normal subjects were established using data from serum $(n=200)$ and urine $(n=29)$ samples collected from healthy blood donors. Matched serum samples $(\mathrm{n}=36$ ) were also collected at 09.00 hours and midnight from healthy volunteers. Reference ranges were calculated as 2.5 and 97.5 percentiles.

\section{Correlation with other immunoassays}

The SR1 Cortisol assay was compared with the following assays:

Diagnostic Products Corporation, Coat-a-Count (radioimmunoassay).

Amerlite Diagnostics Limited, Amerlite (luminescence-enhanced enzyme immunoassay).

Abbott Diagnostics, TDx (fluorescence polarization immunoassay).

Boehringer Mannheim, Enzymun-Test (enzyme immunoassay).

Regression lines were calculated using the method of Passing \& Bablok (10).

\section{Application to urine}

Urine samples were collected without preservative as 24 hour collections. Urinary cortisol values were determined with and without prior sample pretreatment. Briefly, the pretreatment was performed as follows: $500 \mu \mathrm{l}$ of freshly collected urine were extracted in $2.5 \mathrm{ml}$ of ice-cold dichloromethane. Following removal of the solvent by evaporation, the extract was reconstituted in human cortisol-free serum and assayed as a serum sample. The precision and accuracy of the method was similar to that of the serum assay. The average recovery of this method was $96.5 \pm 11.9 \%$. This was assessed by addition of pure cortisol to urine, followed by extraction and calculation of the recovery as recommended (8).

\section{Results}

\section{Precision}

Within and between assay precision are summarised in table 1.

\section{Detection limit}

The detection limit of the assay determined on four occasions was typically less than $5 \mathrm{nmol} / \mathrm{l}$ (mean $=2.7 \mathrm{nmol} / 1$, range $=1.9$ to $3.3 \mathrm{nmol} / \mathrm{l})$. 
Ta.b. 1. Within and between assay precision using control sera

\begin{tabular}{lcl}
\hline Mean $(\mathrm{nmol} / \mathrm{l})$ & S. D. & CV $(\%)$ \\
\hline \multicolumn{2}{l}{ Within-assay precision $(\mathrm{n}=20)$} & \\
8.9 .2 & 8.6 & 9.7 \\
54.8 & 47.5 & 8.6 \\
86.3 & 82.5 & 9.6 \\
\multicolumn{2}{l}{ Between-assay precision $(\mathrm{n}=20)$} & \\
87.6 & 10.1 & 11.5 \\
553 & 45.4 & 8.2 \\
941 & 79.0 & 8.4 \\
\hline
\end{tabular}

Tab. 2. Assay specificity

\begin{tabular}{lc}
\hline Cross reactant & Cross-reaction (\%) \\
\hline Prednisone & 0.9 \\
Prednisolone & 40.1 \\
6-Methylprednisolone & 4.1 \\
11-Deoxycortisol & 5.6 \\
Corticosterone & 1.3 \\
Cortisone & 1.4 \\
11-Deoxycorticosterone & 2.3 \\
17- $\alpha$ Hydroxyprogesterone & 3.4 \\
Dexamethasone & 8.4 \\
Oestradiol & $<0.2$ \\
Oestrone & $<0.2$ \\
Oestriol & $<0.2$ \\
Progesterone & 1.5 \\
Testerone & 1.3 \\
Aldosterone & 5.9 \\
Spironolactone & $<0.2$ \\
Canrenone & $<0.2$ \\
\hline
\end{tabular}

\section{Specificity}

Specificity is summarized in table 2 . Only the pharmaceutical drug prednisolone was found to crossreact significantly.

\section{Recovery and accuracy}

Recovery is summarised in table 3(a). The overall recovery of added cortisol was $101.5 \pm 9.5 \%$.

The BCR control sera were assigned the following values:

$\begin{array}{lll}\text { Control } & \begin{array}{l}\text { ID-MS } \\ \text { target value } \\ (\mathrm{nmol} / \mathrm{l})\end{array} & \begin{array}{l}\text { SR1 value } \\ (\mathrm{Mean} \pm 2.5 \mathrm{SD}) \\ (\mathrm{nmol} / \mathrm{l})\end{array} \\ \mathrm{RM} \mathrm{192} & 273 & 227 \pm 53.2 \\ \text { RM 193 } & 763 & 709 \pm 128\end{array}$

\section{Dilution}

Dilution is summarised in table $3(\mathrm{~b})$. The assay shows good linearity over the dilution range investigated.
Tab. 3. Assay characteristics

a) Recovery of exogenous cortisol

\begin{tabular}{lllr}
\hline $\begin{array}{l}\text { Cortisol } \\
\text { added } \\
\text { (nmol/l) }\end{array}$ & $\begin{array}{l}\text { Number of } \\
\text { samples }\end{array}$ & $\begin{array}{l}\text { Mean } \\
\text { recovery } \\
(\%)\end{array}$ & SD \\
\hline 107 & 5 & 102.6 & 5.3 \\
217 & 5 & 92.6 & 4.2 \\
495 & 5 & 102.9 & 8.4 \\
977 & 5 & 108.0 & 12.5 \\
Overall & 20 & 101.5 & 9.5 \\
\hline
\end{tabular}

b) Dilution characteristics

\begin{tabular}{llcr}
\hline $\begin{array}{l}\text { Dilution } \\
\text { factor }\end{array}$ & $\begin{array}{l}\text { Number of } \\
\text { samples }\end{array}$ & $\begin{array}{l}\text { \% of undil- } \\
\text { uted value }\end{array}$ & SD \\
\hline 1 in 2 & 10 & 99.4 & 5.0 \\
1 in 4 & 10 & 101.2 & 8.2 \\
1 in 8 & 10 & 108.0 & 10.6 \\
Overall & 30 & 102.9 & 8.8 \\
\hline
\end{tabular}

c) Normal reference ranges

\begin{tabular}{|c|c|c|c|c|}
\hline \multicolumn{2}{|l|}{ Group } & $\begin{array}{l}\text { Time of } \\
\text { sampling }\end{array}$ & $\begin{array}{l}\text { Number } \\
\text { in study }\end{array}$ & $\begin{array}{l}\text { Cortisol } \\
\text { in serum } \\
(\mathrm{nmol} / \mathrm{l})\end{array}$ \\
\hline \multirow{6}{*}{\multicolumn{2}{|c|}{$\begin{array}{l}\text { Normal females } \\
\text { Normal males } \\
\text { Normal adults } \\
\text { Normal adults } \\
\text { Pregnant } \\
\text { 3rd trimester }\end{array}$}} & Random & 100 & $97-356$ \\
\hline & & Random & 100 & $106-493$ \\
\hline & & 09.00 & 36 & $134-589$ \\
\hline & & Midnight & 36 & $8-221$ \\
\hline & & & & \\
\hline & & Random & 25 & $276-739$ \\
\hline \multirow[t]{2}{*}{ Group } & \multirow{2}{*}{$\begin{array}{l}\text { Time of } \\
\text { sampling }\end{array}$} & \multirow{2}{*}{$\begin{array}{l}\text { Number } \\
\text { in study }\end{array}$} & \multicolumn{2}{|c|}{ Cortisol in urine } \\
\hline & & & $\begin{array}{l}\text { Extract- } \\
\text { ion pro- } \\
\text { cedure } \\
\text { (nmol/ } \\
24 \text { hours) }\end{array}$ & $\begin{array}{l}\text { Un- } \\
\text { extracted } \\
\text { urine } \\
\text { (nmol/ } \\
24 \text { hours) }\end{array}$ \\
\hline $\begin{array}{l}\text { Normal } \\
\text { adults }\end{array}$ & 24 hour & 29 & $35-253$ & $250-2481$ \\
\hline
\end{tabular}

\section{Expected values}

Table 3(c) shows reference ranges for normal subjects using the SR1 Cortisol assay. These ranges are intended only as a guide and may vary depending on the population studied. They are in good agreement with previously published reference ranges (1). Unextracted urine samples give higher cortisol concentrations than the corresponding extracted samples.

\section{Correlation with other immunoassays}

Figure 1 shows comparisons of cortisol results using four different immunoassays. In general, a good correlation was obtained between SR1 Cortisol and the other products. 

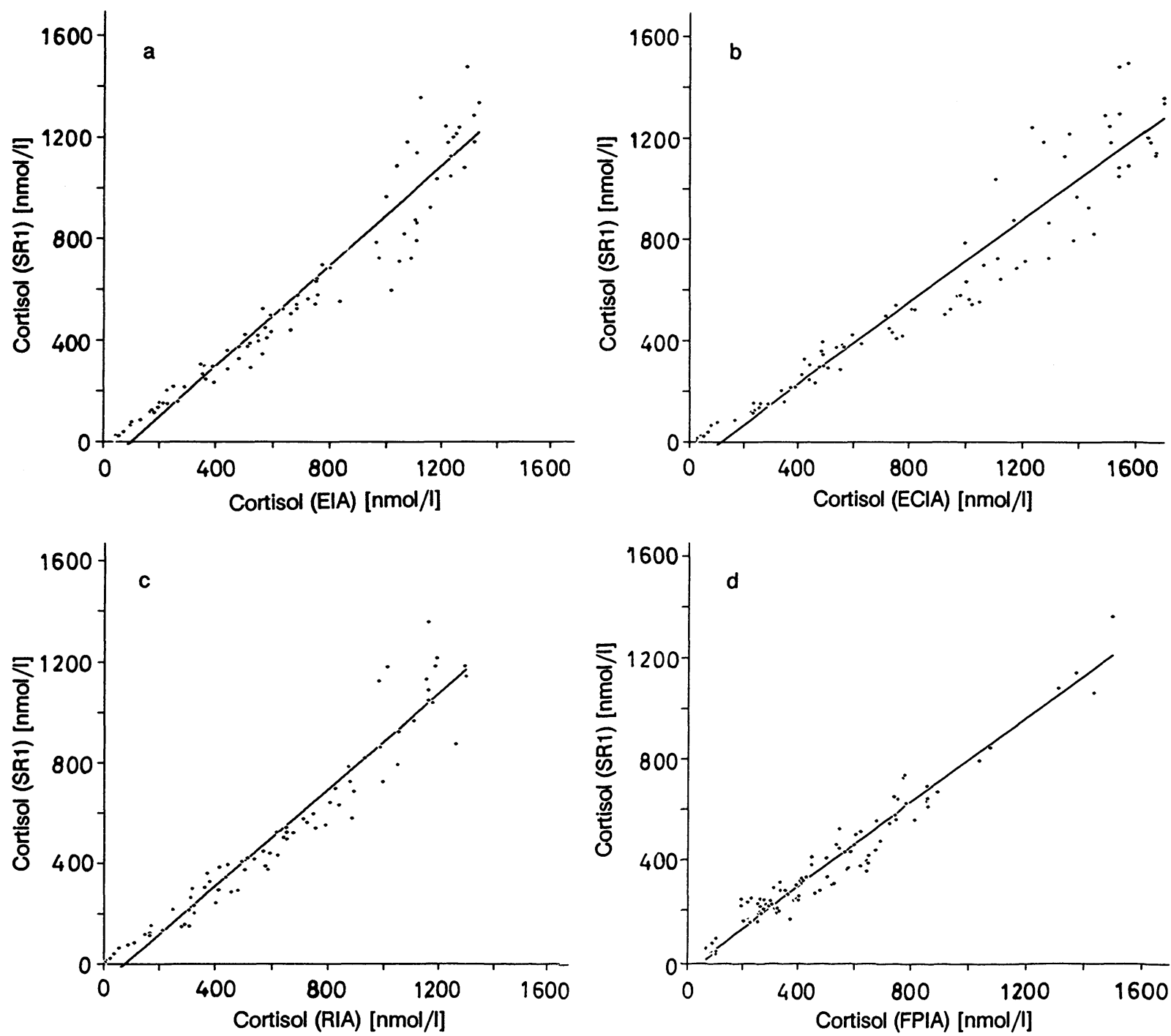

Fig. 1. Correlation of SR1 Cortisol values with

a) enzyme immunoassay, (b) enhanced chemiluminescent immunoassay, (c) radioimmunoassay and (d) fluorescence polarization immunoassay

a) $\mathrm{y}=0.992 \mathrm{x}-100.65 ; \mathrm{n}=85$

b) $\mathrm{y}=0.809 \mathrm{x}-96.62 ; \mathrm{n}=87$

c) $\mathrm{y}=0.954 \mathrm{x}-71.57 ; \mathrm{n}=80$

d) $y=0.844 x-40.56 ; n=95$

\section{Conclusion}

This paper describes the performance of a fully automated enzyme immunoassay for the measurement of cortisol in serum, heparinised plasma and urine. The range $(5-1656 \mathrm{nmol} / \mathrm{l})$ and detection limit $(<5 \mathrm{nmol} / \mathrm{l})$ of the assay make it suitable for all clinical applications of the assay. The assay has good specificity for cortisol. Only prednisolone (a therapeutic drug with marked structural similarity to cortisol) shows a significant cross-reaction. Samples from patients taking prednisolone are therefore contra-indicated. The concentrations of cortisol measured with this assay show good agreement with values measured with other immunoassays and by isotope dilutionmass spectrometry. Urine samples should be extracted prior to assay, because the method co-measures cortisol metabolites in urine.

In conclusion, the SR1 Cortisol assay on the SR1 analyzer fulfills all the necessary criteria for routine clinical analysis. The SR1 provides walk-to, walkaway automation, random access and batch modes of operation and uses stored standard curve calibration. The time to first result for a cortisol assay is 46 minutes and thereafter two results every two minutes. 


\section{References}

1. Zilva, J. \& Pannall, P. (1984) Clinical Chemistry in Diagnosis and Treatment, 4th edn., pp. 138-155, Lloyd-Luke (Medical Books) Ltd., London.

2. Schöneshöfer, M., Weber, B., Ölkers, W., Nahoul, K. \& Mantero, F. (1986) Urinary excretion rates of 15 free steroids: potential utility in differential diagnosis of Cushing's syndrome. Clin. Chem. 32, 93-96.

3. Kowalski, A. \& Paul, W. (1979) A simple extraction procedure for the determination of free cortisol in urine by radioimmunoassay. Clin. Chem. 25, 1152.

4. Wilke, T. \& Hirning, D. (1984) The evaluation of five commercial serum cortisol kits regarding precision and accuracy. Clin. Biochem. 17, 311-316.

5. Westerhius, L. (1988) Measurement of cortisol with EMIT and Amerlite immunoassays. Clin. Chem. 34, 2374.

6. Ayers, G., Clark, J. \& Burrett, D. (1989) An evaluation of the Abbott TDx serum cortisol assay. Ann. Clin. Biochem. $26,294-295$.
7. Tunn, S., Pappert, G., Willnow, P. \& Krieg, M. (1990) Multicentre evaluation of an enzyme-immunoassay for cortisol determination. J. Clin. Chem. Clin. Biochem. 28, 929935 .

8. Thienpont, L., Siekmann, L., Lawson, A., Colinet, E. \& De Leenheer, A. (1991) Development, validation and certification by isotope dilution gas chromatography-mass spectrometry of lyophilized human serum reference materials for cortisol (CRM 192 and 193) and Progesterone (CRM 347 and 348). Clin. Chem. 37, 540-546.

9. European Committee of Clinical Laboratory Standards (ECCLS), Vol. 3, No. 3, October 1986.

10. Passing, H. \& Bablok, W. (1983) A new biological procedure for testing the equality of measurements from two different analytical methods. J. Clin. Chem. Clin. Biochem. $21,701-720$.

Dr T. Bacarese-Hamilton Serono Diagnostics Ltd 21 Woking Business Park Woking

Albert Drive

Surrey GU21 5JY

United Kingdom 
